Гаценко С. С., канд. техн. наук

(0000-0002-0957-6458);

Металіді О. Г.

(0000-0002-4242-5280);

Любарчук К. В.

(0000-0001-7069-6929);

Мазуренко В. М.

(0000-0003-4649-7959);

Савенко В. В.

(0000-0002-5004-1199)

Командно-штабний інститут застосування військ (сил) Національного університету оборони України імені Івана Черняховського, Київ

\title{
Оцінювання тактико-технічних характеристик станцій радіотехнічної розвідки Збройних Сил України та передових країн світу
}

Резюме. У статті проведено оцінювання тактико-технічних характеристик станцій радіотехнічної розвідки, які знаходяться на озброєнні військових частин радіоелектронної розвідки Збройних Сил України та передових країн світу, для удосконалення системи радіоелектронної розвідки як основного технічного виду військової розвідки України для прийняття обгрунтованого рішення щодо закупівлі комплексів РТР закордонного виробництва з використанням методу експертних оцінок.

Ключові слова: оцінювання, радіотехнічна розвідка, радіоелектронна розвідка, експертні оцінки.

Постановка проблеми. Збройна агресія Російської Федерації проти України призвела до втрати важливих промислових потенціалів. Державна акціонерна холдингова компанія “Топаз" спеціалізувалася на розробленні і виробництві складних радіотехнічних систем і комплексів, в тому числі унікальних комплексів дальньої радіотехнічної розвідки (РТР) та раннього попередження систем протиповітряної оборони, зокрема станції радіотехнічної розвідки "Кольчуга". Використання означеної РТР давало змогу вирішити завдання 3 отримання даних про систему протиповітряної і протиракетної оборони противника, їх пункти управління, злітні майданчики, функціонування літакових радіолокаційних станцій та інших військових об'єктів, які використовує противник у системі радіотехнічного забезпечення [1].

На теперішній час на озброєнні військових частин радіоелектронної розвідки (РЕР) Збройних Сил (ЗС) України знаходиться станції РТР типу "Кольчуга". Частка працездатних станцій низька.

Одним із напрямів розв'язання зазначеної проблеми може бути закупівля комплексів РТР для забезпечення частин i підрозділів РЕР ЗС України. Основними закордонними аналогами станцій РТР "Кольчуга" є:

станція РТР виробництва чеської компанії "ERA" - "VERA-NG";

станція РТР китайського виробництва "JW-600" (DWL-NG); станція РТР польського виробництва "PRP-25".

Для прийняття обгрунтованого рішення стосовно закупівлі комплексів РТР закордонного виробництва потрібно оцінити їх тактико-технічні характеристики.

Аналіз останніх досліджень i публікацій. Характеристики станцій i комплексів РТР можуть подаватися як у кількісному, так і якісному вигляді [2]. Різноманітність цих властивостей i характеристик ускладнює порівняння за узагальненими критеріями однакових за призначенням засобів РТР під час закупівлі. Для оцінювання тактико-технічних характеристик станцій РТР може бути використаний метод експертного оцінювання як для визначення доцільності окремих схемотехнічних, конструкторських i технологічних рішень, що приймаються як на стадії розроблення і модернізації комплексів РТР, так i для порівняння їх бойових характеристик i параметрів у різних умовах експлуатації [3].

Експертний метод оцінювання станцій $\mathrm{i}$ комплексів РТР полягає у реалізації процедури отримання відповідної оцінки параметрів, характеристик на основі групової думки спеціалістів (експертів) [4]. Така комплексна, узагальнена думка, звичайно, точніша (тобто об'єктивніша) за індивідуальну думку кожного окремого спеціаліста.

Мета статті. Оцінювання тактикотехнічних характеристик станцій РТР вітчизняного і закордонного виробництва для 
забезпечення частин $\mathrm{i}$ підрозділів РЕР 3С України, 3 використанням методу експертних оцінок.

Виклад основних положень матеріалу. Будь-яка система РТР необхідна для досягнення визначеної мети. Для визначення ступеня відповідності цієї системи чи комплексу РТР меті, яка поставлена перед ним, необхідно ввести відповідні критерії,

$$
W_{k}=a_{1, k} \cdot w_{1, k}+a_{2, k} \cdot w_{2, k}+\ldots+a_{n, k} \cdot w_{n, k}=\sum_{n=1}^{N} a_{n, k} \cdot w_{n, k},
$$

де $W_{k}$ - узагальнений показник оцінювання $k$-го виробу, $k=\overline{1, K}$;

$K$ - тип виробу;

$a_{n, k}-$ ваговий коефіцієнт $n$-го параметра $k$ 20 виробу (за важливістю), $n=\overline{1, N}$,

$N$ - кількість параметрів комплексу РТР, за якими здійснюється порівняння;

$$
w_{n, k} \text { - нормований безрозмірний } n-\check{u}
$$

параметр $k$-го виробу;

$$
w_{n, k}=\frac{x_{n, k}}{x_{n, B}},
$$

де $x_{n, k}-n$-ц̌ параметр $k$-го виробу;

$x_{n, B}-n-\check{u}$ параметр базового (кращого) виробу.

показники оцінювання [9]. Критерії, показники оцінювання мають відображати цільове призначення, мати межі вивчення [10]. Для оцінювання тактико-технічних характеристик станцій РТP беруть узагальнений показник у вигляді лінійної функції, що відображається у його нормованих параметрах:

Одним із методів визначення вагових коефіцієнтів є метод експертних оцінок, який включає підбір експертів, узгодження 3 ними переліку параметрів, складання анкет і експертне опитування, визначення важливості параметрів за рангом.

Відповідно до наукового завдання проведемо оцінювання ефективності таких зразків станцій PTP: "VERA-NG", "JW-600" (DWL-NG), "PRP-25".

Використовуючи метод експертних оцінок, необхідно оцінити тактико-технічну ефективність і порівняльний аналіз цих виробів.

\section{Порядок розрахунку.}

1. Формується табл. 1, де надані параметри комплексів РТР, які підлягають оцінюванню.

\begin{tabular}{|c|c|c|c|c|c|c|}
\hline № & $\begin{array}{c}\text { Основні } \\
\text { характеристики }\end{array}$ & $\begin{array}{c}\text { Кольчуга КЕ } \\
\text { (Україна) }\end{array}$ & $\begin{array}{l}\text { VERA-NG } \\
\text { (Чехiя) }\end{array}$ & $\begin{array}{c}\text { PRP-25 } \\
\text { (Польща) }\end{array}$ & $\begin{array}{l}\text { JW-600 } \\
\text { (Китай) }\end{array}$ & $\begin{array}{c}\text { Базове } \\
\text { значення }\end{array}$ \\
\hline 1 & Діапазон частот (ГГц) & $0,13 \ldots 18,00$ & $0,05 \ldots 18,0$ & $0,5 \ldots 18,0$ & $0,38 \ldots 1,8^{*}$ & 18,0 \\
\hline 2 & $\boldsymbol{D}$ виявлення (км) & $450 \ldots 600$ & 400 & 400 & $300 \ldots 400$ & 600 \\
\hline $\mathbf{3}$ & $\begin{array}{l}\text { Зона огляду по } \\
\text { азимуту (град) }\end{array}$ & $360 / 120$ & $360 / 120$ & $360 / 120$ & 120 & 120 \\
\hline 4 & $\begin{array}{c}\text { Зона огляду по куту } \\
\text { місця (град) }\end{array}$ & $0 \ldots 10-30$ & $0 \ldots 40-60$ & $0 \ldots 40$ & $0 \ldots 40$ & 60 \\
\hline 5 & $\begin{array}{l}\text { Метод визначення } \\
\text { координат джерел }\end{array}$ & $\begin{array}{c}\text { Кутомірний, } \\
\text { різницево- } \\
\text { далекомірний } \\
\text { 2D / 3D } \\
\end{array}$ & $\begin{array}{c}\text { Різницево- } \\
\text { далекомірний } \\
\text { 3D }\end{array}$ & $\begin{array}{c}\text { Кутомірний } \\
\text { Далекомірний } \\
\text { 3D }\end{array}$ & $2 \mathrm{D} / 3 \mathrm{D}$ & $\begin{array}{c}\text { Кутомірний, } \\
\text { різницево- } \\
\text { далекомірний } \\
\text { 2D / 3D } \\
\end{array}$ \\
\hline 6 & $\begin{array}{c}\text { Точність визначення } \\
\text { координат (середньо- } \\
\text { квадратична похибка при } \\
\text { дальності } 150 \text { км, } \\
\text { базі 25-30 км), км } \\
\end{array}$ & $\begin{array}{c}1,5-4,5 \\
(1-3 \% \text { від } \\
\text { дальності) }\end{array}$ & $\begin{array}{c}0,25 \\
\text { (координати) } \\
0,35 \text { (висота) }\end{array}$ & $2-5$ & відсутні дані & $\begin{array}{c}0,25 \\
\text { (координати) } \\
0,35 \text { (висота) }\end{array}$ \\
\hline 7 & $\begin{array}{c}\text { Кількість цілей, що } \\
\text { супроводжуються в } \\
\text { реальному масштабі часу }\end{array}$ & 200 & 200 & до 100 & відсутні дані & 200 \\
\hline 8 & $\begin{array}{c}\text { Бібліотека сигналів } \\
\text { об'єктів розвідки }\end{array}$ & 1000 & 1000 & відсутні дані & відсутні дані & 1000 \\
\hline 9 & Час реагування, с & - & - & - & 3 & 5 \\
\hline 10 & $\begin{array}{c}\text { Час оновлення } \\
\text { даних, с } \\
\end{array}$ & $1-5$ & $1-5$ & відсутні дані & 5 & 5 \\
\hline 11 & $\begin{array}{c}\text { Середній час } \\
\text { напрацювання на } \\
\text { відмову (Тв), год }\end{array}$ & 500 & 2000 & 1000 & 500 & 1000 \\
\hline
\end{tabular}

Таблиця 1

Параметри комплексів радіотехнічної розвідки 
2. Табл. 1 перетворюється у Табл. 2, де наведено нормовані безрозмірні параметри (характеристики) для обраних комплексів РТР, які розраховані за формулою (2).

Таблиця 2

Таблиця безрозмірних значень показників комплексів РТР

\begin{tabular}{|c|c|c|c|c|c|}
\hline № & Основні характеристики & $\begin{array}{c}\text { Кольчуга КЕ } \\
\text { (Україна) }\end{array}$ & $\begin{array}{l}\text { VERA-NG } \\
\text { (Чехія) }\end{array}$ & $\begin{array}{c}\text { PRP-25 } \\
\text { (Польща) }\end{array}$ & $\begin{array}{r}\text { JW-600 } \\
\text { (Китай) }\end{array}$ \\
\hline 1 & Діапазон частот (ГГц) & 1 & 1 & 1 & 1 \\
\hline 2 & Дальність виявлення (км) & 1 & 0,6 & 0,6 & 1 \\
\hline 3 & Зона огляду по азимуту (град) & 1 & 1 & 1 & 1 \\
\hline 4 & $\begin{array}{c}\text { Зона огляду по куту місця } \\
\text { (град) }\end{array}$ & 0,5 & 1 & 1 & 1 \\
\hline 5 & $\begin{array}{c}\text { Метод визначення координат } \\
\text { джерел } \\
\end{array}$ & 1 & 1 & 1 & 1 \\
\hline 6 & $\begin{array}{c}\text { Точність визначення координат } \\
\text { (середньо-квадратична похибка } \\
\text { при дальності } 150 \text { км, } \\
\text { базі 25-30 км), км } \\
\end{array}$ & 1 & 1 & 0.5 & - \\
\hline 7 & $\begin{array}{c}\text { Кількість цілей, що } \\
\text { супроводжуються в реальному } \\
\text { масштабі часі }\end{array}$ & 1 & 1 & 0,5 & - \\
\hline 8 & $\begin{array}{l}\text { Бібліотека сигналів } \\
\text { об'єктів розвідки }\end{array}$ & 1 & 1 & 0 & - \\
\hline 9 & Час реагування, с & 0 & 0 & 0 & 0,6 \\
\hline 10 & Час оновлення даних, с & 1 & 1 & 0 & 1 \\
\hline 11 & $\begin{array}{c}\text { Середній час напрацювання на } \\
\text { відмову (Тв), год }\end{array}$ & 0,5 & 1 & 1 & 0,5 \\
\hline
\end{tabular}

3. Створюється матриця рангів $Q_{n, i}$, $(n=\overline{1, N}$ - характеристика виробу, $i=\overline{1, I}-$ номер експерта, $I=5$ ) шляхом виставлення рангу важливості параметра комплексу РТР кожним експертом. Порядок визначення важливості параметрів сигналів полягає у такому: кожний експерт присвоює найважливішому параметру номер 1, іншим параметрам, за зменшенням ступеня важливості, присвоюються наступні номери. Кількість номерів важливості має відповідати кількості параметрів, за якими здійснюється оцінювання. Результати заносяться у таблицю, яка являє собою матрицю експертного оцінювання важливості параметрів кожного типу комплексу РТР (Табл. 3). У цьому випадку оцінювання проводилося n’ятьма експертами за кожним параметром комплексів PTP.

Матриця рангів важливості параметра комплексів РТР

Таблиця 3

\begin{tabular}{|c|c|c|c|c|c|c|}
\hline \multirow{2}{*}{ № } & \multirow{2}{*}{ Основні характеристики } & \multicolumn{5}{|c|}{ Номери експертів $i,(i=\overline{1,5})$} \\
\hline & & 1 & 2 & 3 & 4 & 5 \\
\hline 1 & Діапазон частот (ГГц) & 5 & 7 & 1 & 8 & 4 \\
\hline 2 & Дальність виявлення (км) & 7 & 5 & 8 & 1 & 3 \\
\hline 3 & Зона огляду по азимуту (град) & 2 & 1 & 9 & 9 & 9 \\
\hline 4 & $\begin{array}{c}\text { Зона огляду по куту місця } \\
\text { (град) }\end{array}$ & 1 & 4 & 10 & 10 & 8 \\
\hline 5 & $\begin{array}{c}\text { Метод визначення координат } \\
\text { джерел } \\
\end{array}$ & 3 & 3 & 3 & 2 & 5 \\
\hline 6 & $\begin{array}{c}\text { Точність визначення координат } \\
\text { (середньо-квадратична похибка } \\
\text { при дальності } 150 \text { км, } \\
\text { базі 25-30 км), км } \\
\end{array}$ & 4 & 6 & 4 & 5 & 6 \\
\hline 7 & $\begin{array}{c}\text { Кількість цілей, що } \\
\text { супроводжуються в реальному } \\
\text { масштабі часу } \\
\end{array}$ & 10 & 9 & 2 & 3 & 1 \\
\hline 8 & Бібліотека об’єктів & 6 & 10 & 5 & 6 & 2 \\
\hline 9 & Час реагування, с & 8 & 2 & 6 & 11 & 10 \\
\hline 10 & Час оновлення даних, с & 9 & 8 & 7 & 7 & 7 \\
\hline 11 & $\begin{array}{c}\text { Середній час напрацювання на } \\
\text { відмову (Тв), год }\end{array}$ & 11 & 11 & 11 & 4 & 11 \\
\hline
\end{tabular}


4. Матриця рангів важливості перетворюється у модифіковану матрицю рангів важливості $Q_{\text {мод }}(n, i)$ за формулою $Q_{\text {мод }}(n, i)=N+1-Q_{n, i}, \quad N=11$ - кількість параметрів, за якими здійснюється оцінювання ефективності (Табл.4).

Таблиця 4

Модифікована матриця рангів важливості параметра комплексів РТР

\begin{tabular}{|c|c|c|c|c|c|c|}
\hline \multirow{2}{*}{ № } & \multirow{2}{*}{ Основні характеристики } & \multicolumn{5}{|c|}{ Номери експертів $i,(i=\overline{1,5})$} \\
\hline & & 1 & 2 & 3 & 4 & 5 \\
\hline 1 & Діапазон частот (ГГц) & 7 & 5 & 11 & 4 & 8 \\
\hline 2 & Дальність виявлення (км) & 5 & 7 & 4 & 11 & 9 \\
\hline 3 & Зона огляду по азимуту (град) & 10 & 11 & 3 & 3 & 3 \\
\hline 4 & $\begin{array}{c}\text { Зона огляду по куту місця } \\
\text { (град) }\end{array}$ & 11 & 8 & 2 & 2 & 4 \\
\hline 5 & $\begin{array}{c}\text { Метод визначення координат } \\
\text { джерел } \\
\end{array}$ & 9 & 9 & 9 & 10 & 7 \\
\hline 6 & $\begin{array}{c}\text { Точність визначення координат } \\
\text { (середньо-квадратична похибка } \\
\text { при дальності } 150 \text { км, } \\
\text { базі 25-30 км), км } \\
\end{array}$ & 8 & 6 & 8 & 7 & 6 \\
\hline 7 & $\begin{array}{c}\text { Кількість цілей, що } \\
\text { супроводжуються в реальному } \\
\text { масштабі часу } \\
\end{array}$ & 2 & 3 & 10 & 9 & 11 \\
\hline 8 & Бібліотека об’єктів & 6 & 2 & 7 & 6 & 10 \\
\hline 9 & Час реагування, с & 4 & 10 & 6 & 1 & 2 \\
\hline 10 & Час оновлення даних, с & 3 & 4 & 5 & 5 & 5 \\
\hline 11 & $\begin{array}{c}\text { Середній час напрацювання на } \\
\text { відмову (Тв), год }\end{array}$ & 1 & 1 & 1 & 8 & 1 \\
\hline
\end{tabular}

5. Розрахунок вагових коефіцієнтів для кожного параметра комплексів РТР 3 використанням показників модифікованої матриці (табл. 4) за формулою

$$
a_{j}=\sum_{i=1}^{I} Q(n, i) / \sum_{n=1}^{N} \sum_{i=1}^{I} Q(n, i),
$$

де $I$ - кількість експертів;

$N$ - кількість параметрів;

$Q(n, i)$ - ранг параметра.

$W_{\text {Кольчуга-KE }}=1,329, W_{\text {VERA }-\mathrm{NG}}=1,67$,

Висновки. Отже, провівши розрахунок тактико-технічних характеристик чотирьох станцій РТР, можна відмітити, що найкращі тактико-технічні характеристики у станції РТР виробництва чеської компанії "ERA" "VERA-NG.

Перспективи подальших досліджень. Завдяки простоті та проведенням нескладних обчислень, метод експертних оцінок дасть змогу провести розрахунок та оцінювання тактико-технічних характеристик не тільки засобів РТР, але й іншого озброєння та військової техніки, що зі свого боку вплине на прийняття ефективних рішень щодо розроблення та закупівлі нових видів
Вагові коефіцієнти кожного параметра комплексів РТР дорівнюють: $a_{1}=0,125 ; a_{2}=$ 0,$121 ; \quad a_{3}=0,14 ; \quad a_{4}=0,15 ; \quad a_{5}=0,102 ;$ $a_{6}=0,14 ; \quad a_{7}=0,141 ; \quad a_{8}=0,16 ; a_{9}=0,17 ;$ $a_{10}=0,18 ; a_{11}=0,29$.

6. Розрахунок узагальненого показника TTX кожного комплексу РТР за формулою (1):

,67, $W_{\text {PRP }-25}=0,915, W_{\text {JW }-600}=1,065$.

озброєння для 3С України та ефективного використання бюджетних коштів.

\section{СПИСОК ВИКОРИСТАНОЇ ЛІТЕРАТУРИ}

1. Донбас і Крим: ціна повернення : монографія / за заг. ред. В. П. Горбуліна, О. С. Власюка, Е. М. Лібанової, О. М. Ляшенко. Київ : НІСД, 2015. $474 \mathrm{c}$.

2. Смірнов Ю.О. Основи радіоелектронної розвідки. Частина 1. Розвідувальноінформаційний процес, основні моделі системи РЕР ефективність і напрями іiі подальшого розвитку. Київ : НДІ ГУР МО України, 2009. $155 \mathrm{c}$.

3. Саати Т. Метод оценивания иерархий. Москва : Радио и связь, 1993. 357 с. 
4. Орлов А. И. Экспертные оценки. Москва : ИВСТЭ, 2002. 498 с.

5. Калашніков Є. М.,

Гаценко С. С., Шишацький А. В. Аналіз характеру сучасних воєнних конфліктів. Challenges of hybrid war: information dimension : International scientific and practical conference proceedings, Vilnius, August 16-17, 2019. Vilnius, 2019. p. 24-27.

6. Варламов I. Д., Гаценко С. С. Аналіз проблем інформаційного забезпечення органів військового управління при плануванні оборонної операції за досвідом проведення Антитерористичної операції на Сході України. Основні напрямки застосування космічних систем та геоінформаційного забезпечення в інтересах національної безпеки $i$ оборони : матеріали науково-практичного семінару. Київ, 2015. С. 35-41.

7. Гончаров Ю. И. Теоретические основы радио и радиотехнической разведки. Ленинград, 1989. $374 \mathrm{c}$.

8. Варламов I. Д., Устименко О. В. , Гаценко С. С. Шляхи удосконалення ведення радіоелектронного моніторингу засобів повітряного нападу. Новітні технології - для захисту повітряного простору : збірник матеріалів 10 наукової конференції Харківського національного університету Повітряних Сил імені Івана Кожедуба. 10-11 квітня 2014 р. Харків, 2014. С. 232-233.

9. Варламов І. Д., Роговець М. А., Гаценко С. С., Бучинський Ю. А. Автоматизована система підтримки прийняття рішення щодо визначення типів джерел радіовипромінювань. Проблеми створення, випробування, застосування та експлуатаџіï складних інформаційних систем : збірник наук. праць ЖВІ імені С.П. Корольова. Житомир, 2017. № 14. С. 146-156.

10. Сницаренко П. М. Методические основы обоснования требований к военным системам дистанционного мониторинга окружающего пространства для выявления и сопровождения подвижных объектов при условии ресурсных ограничений на их создание: Прикладная радиоэлектроника. 2010. Т. 9, № 2. С. 185-192.

Стаття надійшла до редакції 31.01.2020

\section{Evaluation of the tactical and technical characteristics of radio intelligence stations of the Armed Forces of Ukraine and the advanced countries of the world}

\section{Annotation}

The armed aggression of the Russian Federation against Ukraine has led to the loss of important industrial potentials. "Topaz", a state-owned holding company, specializes in the development and production of sophisticated radio engineering systems and complexes, including unique long-range radio-intelligence (RI) complexes and early warning systems for air defense systems, including the Kolchuga radio-intelligence station.

The use of the designated RI made it possible to solve the task of obtaining information on the enemy's air defense and missile defense system, their control points, take-off sites, the operation of aircraft radar stations and other military objects used by the enemy in the radio security system.

At present, military units of the Radio-Electronic Intelligence (REI) of the Armed Forces (AF) of Ukraine are RI stations of the Kolchuga type. The share of working stations is low.

One of the ways to solve this problem may be to purchase RI complexes.

The purpose of the article is to evaluate the tactical and technical characteristics of RI stations of domestic and foreign production for providing parts and subdivisions of the RI of Armed Forces of Ukraine using the method of expert assessments.

The main foreign analogues of RI Kolchuga stations are:

RI station manufactured by Czech "ERA" company - "VERA-NG";

RI station of Chinese production "JW-600" (DWL-NG);

RI station of Polish production "PRP-25".

The tactical and technical characteristics of the four RI stations have been calculated. The best tactical and technical characteristics were found in the RI station manufactured by the Czech company "ERA" - "VERA-NG".

The proposed methodology can be used for the calculation and evaluation of other weapons and military equipment, which will influence the effective decision-making on the development / procurement of new weapons for the Armed Forces of Ukraine and the efficient use of budget funds.

Keywords: efficiency, radio-intelligence, radio-electronic intelligence, expert evaluation. 